\title{
Understanding THE DIFFERENT DimenSIONS OF HuMAN Dignity: ANAlysis OF THE DECISION OF THE CONSTITUTIONAL COURT OF THE RePUblic OF Slovenia on THE »TIto Street« CASE
}

\section{Petra Kleindienst ${ }^{1}$}

\begin{abstract}
In 2011, the Constitutional Court of the Republic of Slovenia made a historical decision on the 'Tito street' case, thereby placing human dignity at the centre of the constitutional order. A few years later, some related doubts not resolved by the Constitutional Court remain. For instance, the Court argues that an exhaustive a priori definition of human dignity is impossible since the notion depends on the development of its historical and ethical substance over time. The question thus arises of why legislation states that human dignity is universal even though it can be perceived as being a product of time and place. In this paper, we strive to answer this question by arguing that human dignity has two dimensions, initial dignity and realised dignity, and interpret the Court's decision from a new angle. Thereby, the aim of this paper is to build a conceptual framework of human dignity and discuss it from a fresh perspective as well as to prove its applicability by presenting Slovenian constitutional case law. The paper offers significant insights into the discussion and may therefore help to improve future interpretations of human dignity in the field of constitutional case law.
\end{abstract}

\section{Keywords}

Human Dignity, Human Rights, Constitution of the Republic of Slovenia, Constitutional Court, Case Law, Democracy

\section{Introduction}

According to the decision of the Constitutional Court of the Republic of Slovenia on the »Tito street « case $^{2}$, the Republic of Slovenia (RS) is substantively defined by the principle of democracy as a constitutional democracy in which the human being and his/her dignity lie at the heart of its existence and functioning. The Constitutional Court

\footnotetext{
${ }^{1}$ School of Advanced Social Studies, Gregorčičeva 19, 5000 Nova Gorica, Slovenia. E-mail: petra.kleindienst@gmail.com.

${ }^{2}$ The Constitutional Court of the Republic of Slovenia. U-I-109/10 from September 26, 2011.
} 
of the RS (hereinafter referred to as the Constitutional Court) stated that human dignity is at the centre of the country's constitutional order and that it is »embedded « in Article 1 of the Constitution of the Republic of Slovenia (hereinafter referred to as the Constitution). It should be noted that human dignity was not only included in the constitutional frame based on this decision, as the wording of the Constitution already mentions dignity in Article 34, which guarantees the right to »personal dignity«. In the »Tito street« case, the petitioners alleged a direct infringement of Article 34 of the Constitution, with the Constitutional Court extending its reasoning to Article 1 of the Constitution and basing its decision on the latter. At the same time, we wonder if any difference exists between the meaning of human dignity in Article 1 and personal dignity in Article 34 of the Constitution. Why did the Constitutional Court »embed « human dignity in Article 1 of the Constitution if the intrinsic value of each human being and the idea of liberal democratic rule already derive from Article 34 of the Constitution, as also explained in the Commentary to the Constitution on that particular article? The fact is that the »Tito street « case does not provide a coherent and unambiguous definition of human dignity, even though this concept is highly relevant.

This paper has two main objectives. First, the paper intends to deepen and upgrade the comprehensive understanding of human dignity in order to clarify references to legal philosophy, legal order and constitutional case law, which sometimes seem contradictory when referring to human dignity. We can observe that human dignity is culturally relative and depends on time and space, while at the same time noting that human dignity cannot be taken away because it is innate, eternal, inalienable, universal and absolute ${ }^{3}$. The aim of this paper is therefore to discuss the theoretical basis of the human dignity concept in a way which will prove useful to both theory and practice.

Second, the theoretical basis of the concept of human dignity will be applied to Slovenian constitutional case law, i.e. the »Tito street« case. Pertaining to this, the paper highlights the relationship between human dignity, which, in line with the Constitutional Court's decision, is directly substantiated in Article 1 of the Constitution, and personal dignity in accordance with Article 34 of the Constitution. On the one hand, this allows an examination of the decision from a completely new perspective, while on the other, it creates a potential principle for future case law.

The paper first presents the existing legal regulation of human dignity at the national, regional and international levels. It then tackles the problem of ambiguity regarding the semantic structures of human dignity. Below, the paper seeks to build a conceptual framework implying that human dignity includes two dimensions, i.e. initial and realised dignity. The paper represents an important contribution, as it proceeds with a conceptual presentation of the argumentation in the »Tito street « case in a fresh light, based on the complete picture of human dignity. More specifically, the paper explains the difference between the meaning of human dignity in Article 1 and personal dignity in Article 34 of the Constitution. Hence, the paper is of great importance and may help to improve future constitutional interpretations of human dignity.

\footnotetext{
${ }^{3}$ See the decision of the Constitutional Court of the RS. U-I-109/10, paragraphs 6 and 11.
} 


\section{Placement of human dignity in international, regional and national laws}

After 1945, human dignity started to be increasingly mentioned in international and humanitarian legal documents, first in the preambles and eventually expanding to the individual articles of such documents. ${ }^{4}$ This sudden change came as a reaction to the $\gg$ appalling loss of civilian life « and »the gruesome revelations of the treatment of minorities $\aleph^{5}$ during the Second World War and the Holocaust. ${ }^{6}$ Such atrocities led to the identification of acts and behaviour that are against human dignity, with the aim of avoiding their repetition.

At the outset, it is necessary to mention some of the key international documents adopted for this purpose. One should not ignore the preamble of the Charter of the United Nations (1945), stating: »... to reaffirm faith in fundamental human rights, in the dignity and worth of the human person... « The Universal Declaration of Human Rights (1948), representing the culmination of the concept's significant historical evolution ${ }^{7}$ and serving as the basis for many legal documents, also mentions dignity in the preamble and in Article 1 continues: »All human beings are born free and equal in dignity and rights $\ll .{ }^{8}$ Acceptance of the Universal Declaration of Human Rights established »the idea that human dignity and human rights are core values which should be respected when pursuing any policy«. In addition, »it establishes that human dignity and rights are afforded to all human beings « and $»$ that all human action must act in accordance with human dignity «. ${ }^{9}$

The importance of human dignity continued to be highlighted when three overarching international human rights treaties were adopted that declared human dignity as a foundational idea $^{10}$ : the International Covenant on Civil and Political Rights (1966), the International Covenant on Economic, Social and Cultural Rights (1966), and the International Convention on the Elimination of All Forms of Racial Discrimination (1965). These documents influenced the passing of several subsequent documents ${ }^{11}$ that prioritise human dignity, thereby helping to expand the intertwining of human dignity with different areas of legal regulation: the rights of children, prohibition against torture, prohibition against sexual harassment, abortion, euthanasia, handling of mortal remains, the rights of asylum seekers, etc.

In its seventh principle, the Helsinki Accords or the Helsinki Final Act (Conference on Security and Co-operation in Europe Final Act 1975) adopted within the OSCE framework advocate the promotion of the effective implementation of human rights and freedoms arising from inherent human dignity. The World Conference on Human Rights (1993)

\footnotetext{
${ }^{4}$ For a detailed description, see Capps (2009), Daly (2012), Monteiro (2014), Hennette-Vauchez (2011), McCrudden (2008), Malpas and Lickiss (2007), Glensy (2011), Rosen (2012).

${ }^{5}$ Chalmers and Ida (2007), p. 157.

${ }^{6}$ See Eckert (2002), Misztal (2012), McCrudden (2008).

${ }^{7}$ McCrudden (2008), p. 656.

${ }^{8}$ The Universal Declaration of Human Rights (1948) also mentions dignity in Articles 22 and 23.

${ }^{9}$ Capps (2009), p. 107.

${ }^{10}$ Chalmers and Ida (2007).

${ }^{11}$ For example, the Convention on the Elimination of All Forms of Discrimination Against Women (1979), the Convention Against Torture and Other Cruel, Inhuman or Degrading Treatment or Punishment (1984), the United Nations Convention on the Rights of the Child (1989), the International Convention on the Protection of the Rights of All Migrant Workers and Members of Their Families (1990), etc.
} 
in Vienna proclaimed human dignity as its fundamental principle, while the Vienna Declaration and Programme of Action (1993) reaffirmed human dignity as the basis for human rights. Today, it would be hard to imagine an international document on human rights that is not based on human dignity. According to Shultziner, »it is apparent that human dignity in international instruments is the foundation and justification for rights and duties: because of human dignity, human beings have rights and duties «. ${ }^{12}$

With references to human dignity in international legal acts starting to spread, this trend has continued at the regional level, for example at the Council of Europe and at the European Union. At the level of the Council of Europe, we should especially mention the very relevant document, the European Convention on Human Rights (ECHR), which, even though its preamble refers to the Universal Declaration of Human Rights, does not explicitly mention human dignity. Unlike the text of the ECHR, human dignity is much more distinctly mentioned in the case law of the European Court of Human Rights (ECtHR), denoted as the very essence of the Convention. ${ }^{13}$ This is emphasised in the ECtHR decision Pretty v. United Kingdom. ${ }^{14}$ Human dignity is also mentioned in certain later documents of the Council of Europe, for example the European Social Charter (1996), the Convention on Human Rights and Biomedicine (1997), etc.

In the European Union context, human dignity is regarded as a general principle to be followed by all Member States. In the primary law of the European Union, human dignity is explicitly mentioned (in writing) only after the Lisbon Treaty (2007) was adopted. The Treaty on European Union provides that the European Union is founded on the values of respect for human dignity which, together with certain other values, is »common to the Member States in a society in which pluralism, non-discrimination, tolerance, justice, solidarity and equality between women and men prevail« (Article 2). Human dignity is also referred to in the preamble of the EU Charter of Fundamental Rights; moreover, its first article is entitled »Human dignity «: »Human dignity is inviolable. It must be respected and protected «. Human dignity has for a long time also been mentioned in secondary European Union law and the case law of the European Court of Justice (ECJ).

We intend to present the characteristics of the Slovenian national legal system in relation to human dignity. The latter was already mentioned in the preamble to the draft version of the Constitution of the $\mathrm{RS}^{15}$, although it no longer explicitly appears in the preamble to the current Constitution of the RS. ${ }^{16}$ On June 25, 1991, the Assembly of the Republic of Slovenia adopted the Basic Constitutional Charter on the Sovereignty and Independence of the Republic of Slovenia (hereinafter referred to as the BCC), whose preamble includes a reference stating that the former Socialist Federal Republic of Yugoslavia did not act as legally regulated state and that it grossly violated human rights. ${ }^{17}$ Already a few years

\footnotetext{
12 Shultziner (2003), p. 3.

${ }^{13}$ See European Court of Justice. OmegaSpielhallen und Automatenaufstellungs - GmbH v. Oberbürgermeisterin der Bundesstadt. Case C-36/02, October 14, 2004. Opinion of Advocate General Stix-Hackl.

${ }^{14}$ European Court of Human Rights (ECtHR). Pretty v. United Kingdom.

${ }^{15}$ The Writers' Constitution (a synonym for the Theses for the Constitution of the Republic of Slovenia) of 1988, the Demos Constitution of 1990 and the Constitution of Podvin from 1990 (Igličar, 2012).

${ }^{16}$ Igličar (2012).

17 The Constitutional Court of the RS. U-I-109/10.
} 
after the BCC was adopted, Constitutional Court judges Dr. Šturm and Dr. Jerovšek, in their concurring opinion on a decision of the Constitutional Court, pointed out that in regard to this historic fact and deriving from its fundamental mission, the preamble to the Constitution of the RS states the democratic constitutional system, which guarantees fundamental human rights and freedoms, as being the most important. Thus, it places human dignity and its spiritual, political and economic freedom at the forefront. ${ }^{18}$

Since the Constitution does not include an explicit, autonomous expression of human dignity, it obviously suffers from a specific dignity deficit. ${ }^{19}$ For example, the German Constitution, unlike the wording of Slovenia's Constitution, directly places human dignity at the very top of constitutional values and principles. Article 1 of the Basic Law of the Federal Republic of Germany states: »Human dignity (»Die Würde des Menschen«) is inviolable«, which also derives from German judicial interpretations. However, early on following the establishment of the independent and autonomous state of Slovenia, we can perceive human dignity's placement at the heart of the democratic system by constitutional case law. The Constitutional Court clearly and unambiguously expressed this position in 2011 in the »Tito street « case, stating that human dignity is directly substantiated in Article 1 of the Constitution of the RS.

Although we can talk about the absence of a clear provision on human dignity, the Constitution of the RS includes the term »dignity« in certain places. Thus, Article 21 of that Constitution guarantees the following: »Respect for human personality and dignity shall be guaranteed in criminal and in all other legal proceedings, as well as during the deprivation of liberty and enforcement of punitive sanctions «. Further, Article 34 of the Constitution contains the $\gg$ right to personal dignity and safety $«{ }^{20}$ The latter raises the already posed question of how to describe the distinction between personal dignity in accordance with Article 34 and human dignity in accordance with the interpretation of Article 1 of the Constitution in so far as we can speak of a clear dividing line between the two articles.

Human dignity is indirectly protected by other constitutional provisions such as the prohibition against torture, equality before the law and the integrity of human life, prohibition against inhuman or degrading treatment, protection of personal freedom, freedom of expression, freedom of conscience, freedom of assembly and association of work, right to social security, prohibition against conducting medical or other scientific experiments without the free consent of the persons involved, prohibition on violence against persons deprived of their liberty in any way, prohibition on extortion of confessions and statements, as well as the rights of the inviolability of human personal integrity, privacy and personal rights, etc. ${ }^{21}$

\footnotetext{
18 The Constitutional Court of the RS. U-I-266/95.

${ }^{19}$ Avbelj (2011).

${ }^{20} \mathrm{Grad}$ and Kaučič (2007).

${ }^{21}$ Ibid.
} 


\section{Vague semantic structure of the human dignity concept}

In line with Waldron, it makes sense to support the finding that the inclusion of human dignity in several legal documents after the Second World War did not mean the constitution of human dignity itself, but that such an action merely recognised and proclaimed the dignity people are born with. ${ }^{22}$ Above all, the events during the Second World War led to the recording and recognition of existing rights that people have always possessed. This means that the adoption of various international documents cannot be understood as the basis for the existence of human dignity, which logically implies another basis for its existence. We intend to focus on discovering and researching this foundation in the next section.

While human dignity is a widely accepted concept integrated into a broad variety of world cultures, the international community has failed to specify its definition. Due to the lack of consensus, the various regional human rights protection systems attribute somewhat different meanings to the idea of human dignity, which when compared are not entirely consistent. Consequently, human dignity can be described as an »essentially contested concept ${ }^{23}$, meaning that it is constantly subject to interpretative analysis. Glensy believes that, despite the growing presence of topics related to human dignity in legal discourse, the idea of its role in law remains insufficiently explored. ${ }^{24}$ Referring to Schachter, without understanding and a reasonably clear general idea of the concept of human dignity it is impossible to outline the specific implications of its implementation. Schachter therefore argues that the importance of dignity is left to an »intuitive understanding ${ }^{25}$ Shultziner describes human dignity as an eclectic and ambiguous concept, pointing out that a number of world views and ideologies are strongly linked to human dignity, which leads to a paradoxical situation precisely because the latter does not have a fixed or specific content. ${ }^{26}$ Waldron suggests that perhaps the controversy over the concept began to arise when people started to more seriously realise and comprehend the claims of human dignity referred to in documents on human rights. ${ }^{27}$ Despite numerous attempts to define the concept and its versatile use in the modern world, mainly because of its deeper foundations and comprehensive doctrines it cannot be labelled a mere cliché. ${ }^{28}$

However, the term human dignity in legal documents remains somewhat vague, ambiguous and unclear. These documents do not define human dignity, but more or less mention it as either a justification for human rights or they link dignity and the worth of a human.

\footnotetext{
22 Waldron (2013).

${ }^{23}$ For the criteria of the »essentially contested concept«, see Gallie (1956). Rodriguez (2015) upgraded the existing criteria of the essentially contested concept with the finding that the assessment of whether or not the concept is essentially contested depends not only on whether the concept's very essence is contested, but also on whether labelling the concept as contested, due to the encounters of different views, contributes to the concept's enhanced clarity, precision and intelligibility - we are talking about the usefulness of the essentially contested concept.

${ }^{24}$ Glensy (2011).

${ }^{25}$ Schachter (1983), p. 849.

${ }^{26}$ Shultziner (2003).

${ }^{27}$ Waldron (2013).

${ }^{28}$ Donnelly (2013).
} 
According to Sensen, there are even no explicit efforts to clarify or justify human dignity in UN documents. He thereby points out that the term human dignity is deliberately kept vague. If one were to specify the meaning of human dignity, it might not fit with some parties' deeply entrenched opinions and beliefs. In this case, as Sensen explains, the whole project might fail. ${ }^{29}$

Despite some attempts to agree on a definition, human dignity remains vague and open to further discussion in several areas. Accordingly, there is a need for clear, unambiguous and analytical guidelines to help clarify and structure its importance. It is also necessary to achieve the consistent interpretation of legal provisions on human dignity. To this end, in the following section we will explore and try to outline the importance and characteristics of human dignity. We intend to present it as a concept with two fundamental dimensions.

\section{Human dignity as a concept: two dimensions of human dignity}

In the previous section, it became clear that contradictions relating to the human dignity concept are appearing at every step. On the one hand, we read the assertions that slavery and degradation can result in the deprivation or violation of human dignity; on the other hand, we read that human dignity cannot be taken away because dignity is constantly possessed by a person irrespective of their actions and the situation in which they find himself/herself. ${ }^{30}$ The possibility of human dignity being taken away implies the need for its legal protection, although this seems unreasonable when considering the statements about human dignity being inalienable and absolute. These inalienable and absolute right characteristics indicate it is impossible to deprive someone of human dignity and therefore negates the need for legal acts to protect it. How then can we begin to reasonably explain the existence of the numerous legal safeguards of human dignity?

First, we need to focus on the question of how to explain the well-known characteristic of the »inalienability « of human dignity. A careful examination shows that a seemingly very clear characteristic can cast doubt on its real and true sense: does the word »inalienable « mean that »no one can « take away or destroy the human dignity of someone else, or that »no one should « take away or destroy it? In other words, whether someone is able to violate or destroy human dignity (inalienability in the »descriptive sense «), or simply if no one may violate or destroy it (inalienability in the »prescriptive sense «)? How can one reasonably answer and substantiate the answer to this question ${ }^{31}$

Let us begin by looking at the first option and assume that the characteristic of »inalienability « means that no one can take human dignity away (i.e. talking about inalienability in the descriptive sense). This implies that no one is able to hurt or destroy human dignity and that human dignity cannot be severed from somebody. Taking these assumptions into account raises a dilemma regarding the existence of the numerous legal documents protecting human dignity. Why is it at all necessary to legally protect something that is impossible to take away or infringe upon? If human dignity is inalienable in a descriptive

\footnotetext{
${ }^{29}$ Sensen (2011).

${ }^{30}$ Pinker (2008). See also Waldron (2009).

${ }^{31}$ See Ni (2014), pp. 174-178.
} 
sense, there is consequently no need to try to specifically protect and consolidate it. ${ }^{32}$ Therefore, the existence of such legal documents in this respect is completely irrational. Our study continues with the second option by assuming that the characteristic of »inalienability « indicates a prohibition on the deprivation or violation of human dignity (inalienability in the »prescriptive sense «). In this case, the word »inalienability« indicates that no one should deprive another person of human dignity. This means that human dignity is a condition of time and space, and depends on the circumstances of a specific situation. In this context, it may happen that in a particular case there is a partial or complete deprivation of human dignity. Such an understanding of the characteristic of inalienability initially appears quite logical, but only until we encounter the characteristic of universality of human dignity. Human dignity's dependence on space and time implies that it is not universal, as proclaimed by legal instruments.

These dilemmas can only find a sensible answer if we consider the fact that the concept of human dignity necessarily needs to be considered in the light of its fundamental dimensions: initial and realised dignity. ${ }^{33}$ Therefore, we shall continue to present both of these dimensions.

Initial dignity, the first dimension of human dignity, implies a person's respectable status ${ }^{34}$ or the status of human absolute intrinsic value. It indicates the dimension of human dignity which belongs to a human being due to the mere fact they are placed within a group of human beings. It stems from human nature as such and distinguishes human beings from members of other species. It thus constitutes a kind of metaphysical element which is inseparably linked to humans and, as such, exists in any space and time (and is therefore universal). Semantically, initial dignity is close to Cohn's understanding of human dignity: dignity is associated with human beings' exceptional position in nature and as a synonym for »human value«, representing man's intrinsic excellence and thereby distinguishing man from other living creatures. ${ }^{35}$ In line with Kant, we can say that man is thus elevated above all other creations. ${ }^{36}$

Given that all human beings are endowed with initial dignity, as human beings, we may conclude that initial dignity is what constitutes the essence of a human being. We could also say that initial dignity is what makes up a human being, which is why it is referred to as a »constitutive element « of man or personal identity. The inseparability of this element and members of the human species is what makes humans exceptional and gives them

\footnotetext{
${ }^{32}$ See Killmister (2010).

${ }^{33}$ Sensen (2011) also used the distinction between the term »initial « and »realised « dignity to explain differences between the traditional and modern paradigms of the human dignity concept (see also Giesinger (2012), pp. 609-620). Formosa and Mackenzie (2014), pp. 875-892, distinguish between »status dignity« and »achievement dignity«; Neuhäuser and Stoecker (2014), pp. 298-309, between »human dignity« and »dignity proper«; Schroeder (2010), pp. 118-125, between »inviolable dignity « and »aspirational dignity«; and Darwall (1977), pp. 36-49, between »recognition-respect « and »status-respect«.

${ }^{34}$ Status indicates a position; a state of belonging to a particular rank, type or group with all the rights, obligations and potential characteristics resulting from this position. Status is respectable if it is a major status with a considerable weight, to which its holder, as well as a fellow man need to respond with respect (see Formosa and Mackenzie, 2014).

${ }^{35}$ Cohn (1983).

${ }^{36}$ Kant (2007), [Ak 9:489].
} 
a special value. Initial dignity goes hand in hand with some of Kant's notions of dignity as an internal, unconditional and incomparable value. According to Kant, having a dignity means to be raised above all price and to admit no equivalent. ${ }^{37}$

Initial dignity is inevitably associated with a person's position or status. This enables that person to command respect and respectful conduct and behaviour with regard to their fellow man. In other words, this situation provides a human being with a baseline position from which they demand that they be treated by others in accordance with the virtue of »humanity«. From this stems the need to respect the right of every human being - from the sheer fact of the existence of their initial dignity. The need to respect a human being suggests that a person should be considered as an objective and never as a means. This thinking finds deep roots in Kant's theory. When taking the concept of human dignity into account, Kant's following practical imperative can be applied: »Act so that you use humanity, as much in your own person as in the person of every other, always at the same time as end and never merely as means «. ${ }^{38}$ This is often called the »dignity principle « or the $»$ principle of humanity $\ll .39$

We upgraded the interpretation of »initial dignity « with characteristics specified by Formosa and Mackenzie when speaking about the »status of dignity«: this is a permanent, stable form of dignity, which does not contain different stages. ${ }^{40}$ It simply exists within human beings, and its scope cannot be measured; it belongs to everyone to exactly the same extent - the extent that makes humans exceptional and excellent. Being human therefore means being a carrier of initial dignity, which implies that it is his/her inalienable humanity which brings respect to an individual.

This interpretation of initial dignity allows us confirm our earlier assumption that the characteristic of »inalienability « indicates that no one has the possibility to take away one's human dignity (inalienability in the descriptive sense). It is necessary to stress here that we are talking about initial dignity, not certain other dimensions of dignity. Initial dignity is what is absolute and universal, it is not subject to time and space, and it cannot be modified, depending on the circumstances of a given case.

Nevertheless, a careful examination of the source of dignity still does not explain the issue noted in this section's introduction: why talk about the need to protect human dignity if it is inalienable (in the descriptive sense)? We have hitherto found that the characteristic of the inalienability of initial dignity implies it cannot be taken away from anyone. This means it is unnecessary to protect initial dignity with legal regulations because it is an integral part of every human being, even though he/she exists in isolation from everything else. We can with certainty establish that the claim it is necessary to protect human dignity cannot refer to the dimension of initial dignity. Logically, does this mean that it refers to the other equally important dimension of human dignity, realised dignity?

\footnotetext{
${ }^{37}$ Kant (2002), [Ak 4: 434-436]) explains how to differentiate price from dignity. That which has a price only has a relative value, meaning that something else could equivalently replace it. An absolute value is the opposite of price dignity.

${ }^{38}$ Kant (2002), [Ak 4:429].

${ }^{39}$ Monteiro (2014), p. 206.

${ }^{40}$ Formosa and Mackenzie (2014), p. 877.
} 
First, let us more closely consider what we mean when talking about realised dignity. Realised dignity is a dimension of human dignity that tells us the extent to which human dignity is realised/implemented in the case of a particular individual. This means that while every human being is born with initial dignity, they do not necessarily simultaneously enjoy realised dignity. ${ }^{41}$ In contrast to initial dignity, realised dignity is in fact precarious and unstable (it may only be temporary). It can have different levels such that someone can have a higher or lower level of realised dignity than their fellow human. ${ }^{42}$ When we say someone has lost their dignity, we are talking of realised dignity. Similarly, »dignified behaviour « also refers to realised dignity and characterises behaviour corresponding to a subject endowed with initial dignity. ${ }^{43}$

The degree of realised dignity in accordance with our concept consists of two elements that are both necessary to fully encapsulate realised dignity:

- man's relation to oneself (self-respect); and

- man's relation to their fellow man (and vice versa).

Realised dignity is therefore reflected in a person's relationship towards him- or herself and towards other people. It represents the dignity that people can perceive and feel when in touch with themselves and their fellow humans. Clearly, one cannot ignore human sociability as a widespread characteristic of human life. Human development, change and prosperity depend on social bonds with others. ${ }^{44}$ Therefore, people's attitude toward particular individuals is an important factor in them achieving their realised dignity. The distinction between initial dignity and realised dignity is recognised by definition by Meyer, who describes dignity as a sense of one's own dignity (we interpret this as realised dignity). Meyer adds that, despite the lack of a sense of dignity (realised dignity), a person still retains the status of deserved respect in accordance with morality (we interpret this as initial dignity) because dignity is an inherent part of human nature. ${ }^{45}$

We would like to emphasise that the existence of initial dignity is completely independent of the existence of realised dignity or of the extent to which dignity has been realised in the real-life case of a certain individual. Namely, initial dignity can exist in a human being's complete isolation from the rest of the world. Even if their realised dignity is completely minimised, a human being still possesses initial dignity as the core of every human being. For example, deprivation and oppression of an individual by society may reduce their realised dignity, yet their initial dignity continues to exist in all its perfection. Even the extreme deprivation of people, such as the degradation of individuals in mass murders during the Second World War, where many people's realised dignity was reduced to an absolute minimum, cannot support the conclusion that their initial human dignity was infringed in any way. It is inalienable (in the descriptive sense) and therefore cannot be subject to deprivation.

\footnotetext{
${ }^{41}$ Formosa and Mackenzie (2014) note that the divide between initial dignity and realised dignity, for example in the case of poverty and deprivation, implies injustice.

${ }^{42}$ Formosa and Mackenzie (2014).

43 Sensen (2011), p. 146.

44 Nussbaum (1992), Formosa and Mackenzie (2014).

${ }^{45}$ Meyer (2002).
} 
On the other hand, it is impossible to defend the existence of realised dignity that exists independently of initial dignity. Namely, realised dignity is based on initial dignity as its spine or the foundation of its function. Without initial dignity, realised dignity would lack a fundamental building block needed for its construction. Initial dignity can be described as a meta-assumption that enables a human being the possibility of self-realisation and respect from other people. Questions about the way and extent to which someone has become self-realised (according to their own conception of a good life), as well as about the degree of respect one commands from others, all refer to realised dignity and do not affect the existence of initial dignity.

Lebech mentions that the principle of human dignity as a universal condition reflected in the highest value of human beings does not in itself have and indeed cannot have a history since it has not been bound by local or time limits in its historical development. ${ }^{46}$ Such indications refer to »initial dignity « (but not to realised dignity), which belongs to people from the very beginning of their existence by virtue of them belonging to the human species. Initial dignity will thus be qualified as a universal status that cannot be relinquished, lost or have its existence limited to a certain area.

Although initial dignity as a universal status has no history, we tend to agree with Lebech that the idea of human dignity itself does have a history. This idea chiefly relates to the recognition of human dignity, or confirmation by people and the international community that dignity indeed belongs to all human beings. ${ }^{47}$ We may conclude that this idea no longer refers to initial dignity, as in this case we are already talking about realised dignity. The argument that human dignity cannot be taken away is therefore true provided that the claim refers to initial dignity. Yet the assertion that human dignity can be violated is also true, always supposing that the claim relates to realised dignity. And which of these two fundamental dimensions of human dignity requires legal protection? As indicated, legal protection is not required for initial dignity (because it is inalienable in descriptive terms, this means it cannot be removed). It is crucially important that this is not the case for the other dimension of human dignity, i.e. realised dignity. Realised dignity is the very reason for legally protecting human dignity. The function of law and institutions is to achieve large-scale realised dignity or to provide correcting and sanctioning where realisation of the latter is infringed upon.

It is necessary to stress that realised dignity can often be recognised within the human rights framework, even though it is not even explicitly mentioned. Human rights may directly or indirectly indicate it; it is only important that one knows how to perceive it, or at least subconsciously act according to it. Waldron also notes that the presence of dignity as a criterion for determining suitable treatment is explicit in some cases and implicit in others. $^{48}$

\footnotetext{
${ }^{46}$ Lebech (2004).

${ }^{47}$ Ibid.

${ }^{48}$ Waldron (2013).
} 


\section{Diagram 1: Human dignity}

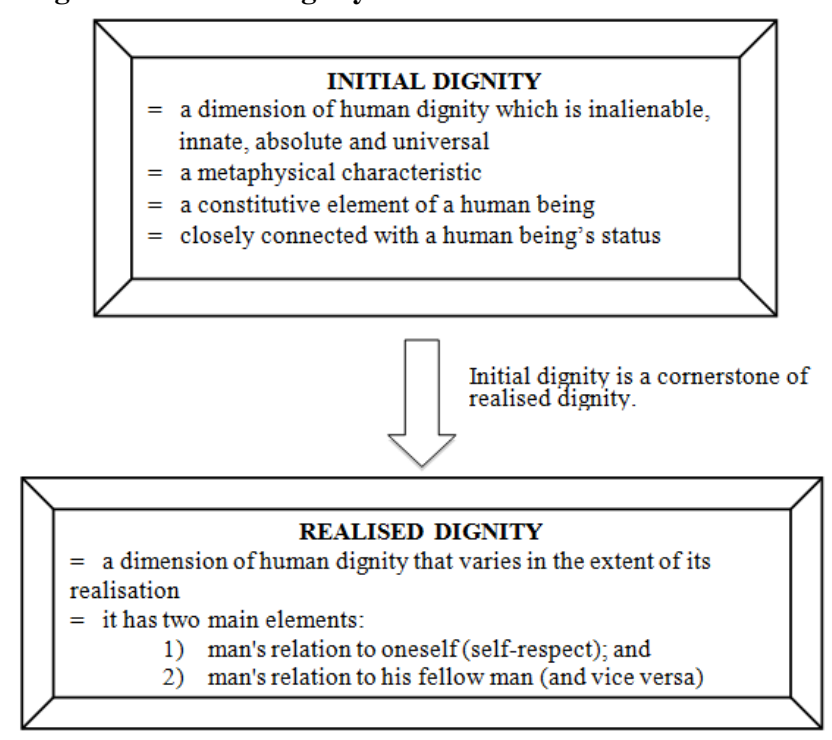

Source: Author

In this section, we outlined the theory of human dignity as a concept containing two fundamental dimensions, both of which were carefully explained. In the following, we are interested in how the presented concept can be applied in constitutional case law. We will rely on the »Tito street« case, in which human dignity holds the key.

\section{The Constitutional Court's Understanding of Human Dignity}

\section{The »Tito street « case}

The theory of human dignity described in the previous section will be used here to provide a basis for interpreting constitutional case law. We shall examine the Constitutional Court's 2011 decision (the »Tito street « case) and determine how it can be substantiated in the light of our theory. To this end, we shall first outline the facts of the case and the grounds on which the Constitutional Court made its decision.

In the »Tito street « case, the constitutional petitioners ${ }^{49}$ challenged Article 2 of the Ordinance on Determining and Changing the Names and Course of the Roads and Streets in the Territory of the Municipality of Ljubljana (hereinafter referred to as the Ordinance),

\footnotetext{
${ }^{49}$ The constitutional petitioners were: Jernej Vrtovec, Lidija Drobnič, Franci Slak and Ignac Polajnar. For the substantiation of their legal interest, see Constitutional Court of the RS. U-I-109/10, paragraph 1. The Constitutional Court ruled that a legal interest was clearly demonstrated by the petitioner Lidija Drobnič, who was recognised as a former political prisoner by a decision of the Commission of the Government of the Republic of Slovenia. Therefore, the Constitutional Court did not rule on the legal interests of the other petitioners (The Constitutional Court of the RS. U-I-109/10, paragraph 2).
} 
regulating the name and course of "Tito Street" in the Municipality of Ljubljana (hereinafter referred to as the MOL). The petitioners contended that naming the street after Josip Broz Tito had violated the right to personal dignity under Article 34 of the Constitution of the $\mathrm{RS}^{50}$ since, in their view, Josip Broz Tito embodied the former communist regime in the Socialist Federal Republic of Yugoslavia. Despite certain positive actions, Josip Broz Tito was historically a negative person, non-democratic and a dictator for whom human rights and fundamental freedoms were unimportant, consequently evoking memories of the people killed by the communist regime. ${ }^{51}$ The opposing party in the constitutional process (MOL) cited several arguments in favour of naming the street after Josip Broz Tito, portraying him as an important personality who played a significant historical role from both the perspective of the territory of present-day Slovenia, and the perspective of other countries. ${ }^{52}$

The Constitutional Court examined the compliance of Article 2 of the Ordinance, reintroducing the name "Tito Street" in Ljubljana, by considering the principle of respect for human dignity. It pointed out that it is necessary to consider the public interest ${ }^{53}$ when naming public spaces, while the symbolic meaning of such actions by the authorities should also not be overlooked. Naming public spaces based on historical events or historical figures also highlights and exposes the social values denoting such events or personalities. With the symbolic naming of public spaces, the authorities give recognition to these values, support them or identify themselves with them, thereby also contributing to their spreading and strengthening. ${ }^{54}$

The Constitutional Court stated that the symbolic dimension of Tito Street is associated with the symbolic meaning of the name of Josip Broz Tito, who is inevitably associated with the totalitarian communist regime marked by gross violations of human rights and fundamental freedoms. Therefore, the symbolic importance of Tito cannot only be seen in light of the relevance of his historical role and personality, as the MOL had stressed in the process. Namely, not only are the purposes or aims of introducing the name "Tito Street" important, but the fact it can »objectively« be seen as »recognition of the former non-democratic regime $\ll$ is essential. ${ }^{55}$

Based on the above, by referring to the objective meaning of the symbol of Tito, the Constitutional Court ruled that Article 2 of the Ordinance was unconstitutional because it violates the principle of respect for human dignity and annulled the mentioned Article. The Constitutional Court decision mentions human dignity as the »highest ethical value ${ }^{56}$, the »fundamental value and legal starting point of Slovenian democracy « ${ }^{57}$, »the fundamental

\footnotetext{
50 The constitutional petitioners also alleged a violation of Article 63 of the Constitution of the RS (see The Constitutional Court of the RS. U-I-109/10, paragraph 2).

51 The Constitutional Court of the RS. U-I-109/10, paragraphs 1 and 2.

52 The Constitutional Court of the RS. U-I-109/10, paragraph 3.

53 Public interest primarily relates to the practical purpose of naming a public space in the sense of ensuring its better everyday functioning (see The Constitutional Court of the RS. U-I-109/10, paragraph 13).

54 The Constitutional Court of the RS. U-I-109/10, paragraph 13.

55 The Constitutional Court of the RS. U-I-109/10, paragraph 15.

56 The Constitutional Court of the RS. U-I-109/10, paragraph 6.

57 The Constitutional Court of the RS. U-I-109/10, paragraph 4.
} 
value which permeates the entire legal order « and »the presumption that every human being has equal and absolute inner worth because he or she is a human being « ${ }^{58}$. The principle of human dignity is substantiated in Article 1 of the Constitution of the RS and constitutes a restriction on the decision-making of democratically elected representative bodies. Interference with this principle therefore represents a direct violation of the fundamental constitutional principle of Article 1 of the Constitution, stating that Slovenia is a democratic republic. Thus, the Constitutional Court attributed special importance to the protection of human dignity. In some countries, this was already included among the fundamental principles of their constitutions. With the decision on the $\gg$ Tito street« case, the Constitutional Court was supposed to do exactly that for the Republic of Slovenia. The Constitutional Court's decision in this case was unanimous, indicating the relevance of consolidating human dignity. Despite the unanimous decision, the Constitutional Court judges were inconsistent in their decisions, as witnessed by the five concurring opinions. The decision was deemed by Avbelj to be an incomplete theoretical agreement, identifying a good starting point for the development of a future doctrine on the protection of human dignity. In addition, Avbelj highlights issues of a constitutional and epistemologicalhermeneutical nature left untackled by the decision. From the constitutional point of view, he asks how can the decision on the »Tito street « case refer only to new naming after symbols of the totalitarian past, but not to already existing denominations, since a violation of human dignity also occurs in the case of a state's passive conduct (e.g. if the state does not remove the existing totalitarian symbols), and not only through its active conduct (prohibition against raising new totalitarian symbols). ${ }^{59}$

Further, there is the question of the existence of a legal interest ${ }^{60}$; also open is the question of why the Constitutional Court only refers to a vertical effect (individual-authorities) of violations of human dignity due to totalitarian symbols, while disregarding the horizontal effect (individual-individual). Finally, there is a question of an epistemological-hermeneutic nature. According to the Constitutional Court, the purpose of the procedure was neither to assess the personality and specific actions of Josip Broz Tito, nor to historically assess the actual facts and circumstances. The Constitutional Court only answered the question of whether a symbol of the former state, taking the objective significance of that symbol into account, is compatible with the constitutional system. As Avbelj points out, from an epistemological-hermeneutic perspective, such an assessment is impossible without the interpretation of historical facts. ${ }^{61}$ We should mention a comment by Pavčnik which refers to an indication of the Constitutional Court stating that, by adopting the independence documents of the Republic of Slovenia, there was not only an interruption of the state law connection between the Republic of Slovenia and SFR Yugoslavia, but a fundamental break with the value concept of the constitutional order. Viewed from a legal perspective, Pavčnik considers that such a statement is inconsistent with the principle of legal conti-

\footnotetext{
${ }^{58}$ The Constitutional Court of the RS. U-I-109/10, paragraph 8.

${ }^{59}$ Avbelj (2011).

${ }^{60}$ See the concurring opinion of Constitutional Court judges Jan Zobec and Miroslav Mozetič, M.Sc., as opposed to the concurring opinions of Constitutional Court judges Jadranka Sovdat, M.Sc. and Dr. Ernest Petrič.

${ }^{61}$ Avbelj (2011).
} 
nuity which was adopted when the Republic of Slovenia declared itself a sovereign and independent state. ${ }^{62}$

We have mentioned certain internally inconsistent or incoherent statements of the Constitutional Court in the »Tito street « case. Many questions remain unsettled and will surely be the subject of further constitutional and legal interpretations in the future. However, we believe that a clearer picture can be obtained by placing the primary focus on the very essence of the »Tito street « case: the inclusion of human dignity in Article 1 of the Constitution of the RS. For this purpose, it is necessary to first understand the concept of human dignity's importance and clarify its role in the Slovenian constitutional field. Therefore, by applying the concept of human dignity theoretically constructed in the previous section, we will substantiate and highlight the decision of the Constitutional Court.

\section{Applicability of the concept of human dignity}

As we have seen, the human dignity concept has two main dimensions, i.e. initial and realised dignity. The question arises as to which of these dimensions of human dignity may be attached to the dignity identified by the Constitutional Court in its argumentation of its decision on the »Tito street « case. The constitutional petitioners alleged a violation of Article 34 of the Constitution of the RS, which guarantees the right to personal dignity and security. It follows from the Commentary to the Constitution of the RS pertaining to Article 34 that the notion that a man has his/her own value constitutes the starting point for the fundamental arrangement of a free democratic society. ${ }^{63}$ This means that Article 34 of the Constitution includes the idea of the exceptional value of a human being and the idea of a free democratic constitutional system which places human dignity at the forefront. It is not completely clear why with its decision the Constitutional Court also embedded human dignity in Article 1 of the Constitution.

One possible interpretation of such Constitutional Court conduct is convergence with international standards and the constitutional arrangements of certain other countries, and the tendency to emphasise the relevance of human dignity in a democratic society. Nevertheless, such emphasising cannot be characterised by conduct of a practical nature since it is virtually a duplication of the already written - as previously stated, the recognition of human value and its correlation with the democratic system is already stated in Article 34 of the Constitution of the RS. Therefore, we assume it is rational to consider a possible distinction within the meaning of human dignity in Article 1 and Article 34 of the Constitution. Our goal in this paper is to reasonably explain this difference by considering the two dimensions of human dignity, i.e. initial and realised. To the extent that our theoretical concept from the previous section proves to be applicable in the constitutional field, it could serve as a guideline for future constitutional case law. In this way, the contradiction in the meaning of human dignity might be reduced somewhat.

Article 1 of the Constitution of the RS, in accordance with the Constitutional Court's decision, primarily emphasises immanent, indivisible, innate human dignity; the equal

${ }_{62}$ Pavčnik (2011); The Constitutional Court of the RS. U-I-109/10, paragraph 7.

63 Šturm (Ed.) (2002). 
and absolute value of a human being and the fact that man and his dignity lie at the heart of the existence and functioning of a democratic state. Thus, we can conclude that, with its decision pertaining to Article 1 of the Constitution, the Constitutional Court in fact indicated the dimension of initial dignity (although under a different designation) - that is to say, the dimension of dignity that is innate and inalienable, meaning that in its essence it cannot be taken away from a person or infringed upon. The Constitutional Court, in reference to Article 1 of the Constitution, therefore recognised and highlighted initial dignity.

Any reference to initial dignity requires extreme caution. Highlighting the possibility of an infringement of (initial) dignity in terms of Article 1 of the Constitution of the RS could namely be perceived as an incorrect understanding of the concept of human dignity. Legal protection of initial dignity under Article 1 of the Constitution is not particularly relevant because this dimension of dignity represents a metaphysical assumption existing within the human being itself and cannot be the subject of any deprivation or violation.

The possibility of violations or threats to human dignity and, consequently, its protection undoubtedly fall within the scope of Article 34 of the Constitution - realised dignity, meaning the dignity possessed by a human being to a greater or lesser extent, and which is not necessarily permanent as it may be merely temporary. The scope of protection afforded by Article 34 of the Constitution in particular implies that the national authorities and all individuals without exception are obliged to respect the right to personal dignity and safety. On the one hand, the right to personal dignity and safety is a defensive right against interference from state authorities and individuals, while on the other hand, the state is obliged to guarantee the right to personal dignity and security. ${ }^{64}$ Prohibition against interference with the right to personal dignity as well as potential conflicts of this right with other constitutional rights suggest that personal (realised) dignity may be subject to violations and threats.

The mention of protecting (initial) human dignity in terms of Article 1 of the Constitution therefore does not make sense since such action has no practical purpose. Embedding human dignity in Article 1 of the Constitution can be explained by arguing that the Constitutional Court was thus stressing the inalienable essence of man and his/her relationship with a democratic system, thereby establishing the existence of initial dignity. Based on these findings, the importance of initial dignity differs substantially from the meaning of realised dignity, which may be the subject of individual violations in the relationship of man with himself and with his/her fellow men, therefore representing a significant reason for the tendency to protect human dignity. The Constitutional Court also constructed a complete picture of human dignity: initial dignity in accordance with Article 1 and realised dignity in accordance with Article 34 of the Constitution of the RS; together, they form an indivisible whole; without each other, they simply cannot exist in all their grandeur.

Taking the presented concept of human dignity into account, it is possible to add the fundamental segment to avoid incoherence in the constitutional interpretation of human

${ }^{64}$ Šturm (Ed.) (2002). See, for example, Constitutional Court of RS. U-I-266/95, 20.11.1995; U-I-158/95, 2.4.1998; U-I-25/95, 27.11.1997. 
dignity. Initial dignity as a meta-assumption which can be articulated only according to a tautological premise is based on Article 1 of the Constitution of the RS. This shows the need for the existence of initial dignity for realised dignity since the latter is »hollow « without initial dignity. We may claim that initial dignity is a fundamental building block of realised dignity - the latter is not absolute and should be protected by legal instruments. Regarding the presented understanding of human dignity, one cannot ignore Kelsen's pure theory of law. Thinking about two dimensions of human dignity in fact leads to the idea that it is possible to outline similarities between the characteristics of initial dignity and Kelsen's »basic norm $\ll{ }^{65}$ Kelsen regarded the legal system as a hierarchy of norms in which each norm derives from another, which is superior to the first norm. Higher norms, therefore, authorise the creation of lower norms and represent the basis for their validity. Nevertheless, a hierarchical chain of applicable norms does not lead to infinity as it is structured from the common basis called the basic norm (»Grundnorm«). The interconnected system of legal norms or the entire legal system therefore originate from one source - the norm of the highest order, which represents a condition for the validity of all other norms. The highest norm is not derived from something higher, but is understood as a norm of a metaphysical nature or a hypothetical assumption with an abstract structure. ${ }^{66}$

The question is whether initial dignity can be considered in the light of Kelsen's basic norm. A positive answer to this question would mean that a constitution as the highest national legal act stems from initial dignity. In this case, the latter does not merely represent the foundation of realised dignity, but forms the basis of the entire legal system. If, relying on legal documents, we assume that the democratic legal order is based on human dignity which forms the origin of all other rights, such a conclusion might be possible. When human dignity (i.e. initial dignity) is recognised as a starting point of democratic rule, we can identify elements of Kelsen's basic norm within it. Initial dignity in terms of Kelsen's theory represents an assumption of everything else and gives individuals the opportunity of self-realisation. It is essential to consider that self-realisation (and thus realised dignity) is impossible without the existence of the basic norm, i.e. initial dignity.

\section{Conclusion}

The paper presented and developed the notion that it is necessary to perceive human dignity as a concept with two basic components. Such a concept explains the seemingly mutually incoherent arguments that human dignity is universal and that it is a condition of time and space. Regarding the theoretical framework presented in this paper, it is clear that the first argument relates to initial dignity and the other to realised dignity. The dimension of initial dignity marks the universal and absolute component of human dignity, giving a human being a special position, and exists at any time and any place. Contrary to initial dignity, the dimension of realised dignity is relative and not necessarily stable. Therefore, it has

\footnotetext{
${ }^{65}$ Kelsen (1967) believed that law should not deal with specific life events (»what is«, »Sein«), but with norms (»what should be«, »Soll«). As a legal positivist, he wanted to separate law from political and ideological additions.

${ }^{66}$ Kelsen (1967).
} 
no pre-determined and steady scope for each individual, but remains subject to different interpretations with the aim of seeking a common, basic essence that can be attributed to it in different cultures and environments. In addition, we need to stress the relevance of initial dignity as the basis for a fundamental pace towards realised dignity. We believe that the understanding of human dignity presented above is a good way to reach the goal of moving beyond the status quo regarding the unclear definition of human dignity. In this way, we may be one step closer towards the true development of this concept.

In this paper, we tested the concept of human dignity's applicability in the constitutional context. We found that it is possible to delineate the boundary between initial and realised dignity, and illustrated their relationship. We explained how realised dignity depends on initial dignity and stressed the need to legally protect the former (unlike initial dignity). The subject of a constitutional complaint can include a violation of Article 34 of the Constitution of the RS, but not of Article 1. After closer examination, it is clear that the purpose of Article 34 is above all the protection of »personal dignity « (i.e. realised dignity) as it is called in accordance with the Constitution of the RS, and ensuring legal institutions that can be used as protection when this right is interfered with. On the other hand, Article 1 of the Constitution especially highlights the relevance of initial dignity, constituting a human being as an integral part of them and therefore not demanding any special protection.

Further research should focus on the question of the relationship between the concept of human dignity and human rights. Describing human dignity as the foundation and origin of human rights is not unusual. Upon closer inspection, however, one can quickly find that the pertaining legal acts are not entirely consistent, as it is possible to trace references to human rights and human dignity as the two ideas are mutually coordinated in a horizontal relationship and mutually adapted. Perhaps this is just an inconsistency in citing, of a rhetorical nature, but perhaps this issue also requires a profound philosophical and legal interpretation. The basis for this question could chiefly be represented by the scheme of human dignity presented in this paper. But such a discussion should already be regarded as the introduction to a new, separate paper.

\section{References}

Avbelj, M. (2011). Zgodovinska odločitev Ustavnega sodišča. Pravna praksa, 39-40, 17-19.

Capps, P. (2009). Human Dignity and the Foundations of International Law. Oxford: Hart Publishing.

Chalmers, D. and Ida, R. (2007). On the International Legal Aspects of Human Dignity. In Malpas, J. and Lickiss, N. (eds.). Perspectives on Human Dignity: A Conversation. Dordrecht: Springer Netherlands.

Charter of the United Nations. (1945). Retrieved September 12, 2016, from http://www.un. org.

Cohn, H. H. (1983). On the Meaning of Human Dignity. In Yoram Dinstein (ed.), Israel Yearbook on human rights (pp. 226-251), Vol. 13. Tel Aviv: Faculty of Law, Tel Aviv University. 
Conference on Security and Co-operation in Europe Final Act. (1975). Retrieved September 12, 2016, from http://www.osce.org.

Convention against Torture and Other Cruel, Inhuman or Degrading Treatment or Punishment. (1984). Retrieved September 12, 2016, from http://www.ohchr.org.

Convention for the protection of Human Rights and Dignity of the Human Being with regard to the Application of Biology and Medicine: Convention on Human Rights and Biomedicine. ETS 164. (1997). Retrieved September 12, 2016, from http://www.coe.int. Convention on the Elimination of All Forms of Discrimination against Women. (1979). Retrieved September 12, 2016, from http://www.ohchr.org.

Convention on the Rights of the Child. (1989). Retrieved September 12, 2016, from http://www.ohchr.org.

Daly, E. (2012). Dignity Rights: Courts, Constitutions, and the Worth of the Human Person. Philadelphia: University of Pennsylvania Press.

Darwall, S. (1977). Two Kinds of Respect. Ethics 88, 1, 36-49.

Donnelly, J. (2013). Universal human rights in theory and practice. New York: Cornell University Press.

Eckert, J. (2002). Legal Roots of Human Dignity in German Law. In Kretzmer, D. and Klein, E. (eds.). The concept of human dignity in human rights discourse (pp. 41-52). The Hague: Kluwer Law International.

European Convention for the Protection of Human Rights and Fundamental Freedoms. ETS 5. (1950). Retrieved September 12, 2016, from http://www.echr.coe.int.

European Court of Human Rights (ECtHR). Pretty v. United Kingdom. Case 2346/02, April 29, 2002. Retrieved September 26, 2016, from http://hudoc.echr.coe.int.

European Court of Justice. OmegaSpielhallen und Automatenaufstellungs - GmbHv. Oberbürgermeisterin der Bundesstadt. Case C-36/02, October 14, 2004. Opinion of Advocate General Stix-Hackl. Retrieved September 29, 2016, from http://curia.europa.eu/juris/showPdf.jsf?text=\&docid=49004\&pageIndex=0\&doclang=en\&mode=lst\&dir=\&occ=first \&pa$\mathrm{rt}=1 \& \mathrm{cid}=239665$.

European Social Charter (Revised). ETS 163. (1996). Retrieved September 26, 2016, from http://www.coe.int.

Formosa, P. and Mackenzie, C. (2014). Nussbaum, Kant, and the Capabilities Approach to Dignity. Ethical Theory and Moral Practice, January: 1-18.

Gallie, W. B. (1956). Essentially contested concepts. Proceedings of the Aristotelian Society, 56, 167-198.

Giesinger, J. (2012). Kant on Dignity and Education. Educational Theory, 62(6), 609-20. Glensy, R. D. (2011). The Right to Dignity. Columbia Human Rights Law Review, 43, 65-142.

Grad, F. and Kaučič, I. (2007). Ustavna ureditev Slovenije. Ljubljana: GV Založba.

Hennette-Vauchez, S. (2011). A human dignitas? Remnants of the ancient legal concept in contemporary dignity jurisprudence. Int J Constitutional Law, 9(1), 32-57.

Igličar, A. (2012). Vrednote v zakonodajni dejavnosti. In B. Kečanović (ed.). Javna etika in integriteta: odgovornost za skupne vrednote. Integriteta, odgovornosti, vladavina prava (pp. 189-199). Ljubljana: Komisija za preprečevanje korupcije. 
International Convention on Civil and Political Rights. (1966). Retrieved September 26, 2016, from http://www.ohchr.org.

International Convention on Economic, Social and Cultural Rights. (1966). Retrieved September 24, 2016, from http://www.ohchr.org.

International Convention on the Elimination of All Forms of Racial Discrimination. (1965). Retrieved September 26, 2016, from http://www.ohchr.org.

International Convention on the Protection of the Rights of All Migrant Workers and Members of Their Families. (1990). Retrieved September 26, 2016, from http://www.ohchr.org. Kant, I. (2002). Groundwork for the Metaphysics of Moral. Wood, A. W. (trans. and ed.). New Heaven: Yale University Press.

Kant, I. (2007). Anthropology, History, and Education. Louden, R. B. and Zöller, G. (eds.). Cambridge: Cambridge University Press.

Kelsen, H. (1967). Pure Theory of Law. Knight, M. (trans.). Berkeley: University of California Press.

Killmister, S. (2010). Dignity: not such a useless concept. Journal of Medical Ethics, 36, 160-164.

Lebech, M. (2004). What Is Human Dignity? Maynooth Philosophical Papers, 2, 59-69. Malpas, J. and Lickiss, N. (eds.). (2007). Perspectives on Human Dignity: A Conversation. Dordrecht: Springer Netherlands.

McCrudden, C. (2008). Human Dignity and Judicial Interpretation of Human Rights. European Journal of International Law, 19(4), 655-724.

Meyer, M. (2002). Dignity as a (modern) virtue. In Kretzmer, D. and Klein, E. (eds.). The concept of Human Dignity in the Human Rights discourse (pp. 195-207). The Hague: Klawer Law International.

Misztal, B. A. (2012). The idea of dignity: Its modern significance. European Journal of Social Justice, 16(1), 101-121.

Monteiro, A. R. (2014). Ethics of Human Rights. Springer International Publishing.

Neuhäuser, C. and Stoecker, R. (2014). Human dignity as universal nobility. In Düwell, M.; Braarvig, J.; Brownsword, R. and Mieth, D. (eds.). The Cambridge Handbook of Human Dignity: Interdisciplinary Perspectives (pp. 298-309). Cambridge: Cambridge University Press.

Ni, P. (2014). Seek and You Will Find It; Let Go and You Will Lose It: Exploring a Confucian Approach to Human Dignity. Dao, 13, 173-98.

Nussbaum, M. C. (1992). Human Functioning and Social Justice: in Defense of Aristotelian Essentialism. Political Theory, 20(2), 202-246.

Pavčnik, M. (2011). Krhkost človekovega dostojanstva. Pravnik, 66 (9/10), 533-541.

Pinker, S. (2008). The Stupidity of Dignity. New Republic. Retrieved Decmber 15, 2016, from https://newrepublic.com/article/64674/the-stupidity-dignity.

Rodriguez, P. A. (2015). Human dignity as an essentially contested concept. Cambridge Review of International Affairs, 28(4), 743-756.

Rosen, M. (2012). Dignity. Its History and Meaning. Cambridge, Mass: Harvard University Press. 
Schachter, O. (1983). Human Dignity as a Normative Concept. American Journal of International Law, 77, 848-854.

Schroeder, D. (2010). Dignity: one, two, three, four, five, still counting. Cambridge Quarterly of Healthcare Ethics, 19(1), 118-125.

Sensen, O. (2011). Kant on Human Dignity. Berlin/Boston: Walter de Gruyter.

Shultziner, D. (2003). Human Dignity - Functions and Meanings. Global Jurists Topics, 3(3), 1-21.

Šturm, L. (ed.). (2002). Komentar Ustave Republike Slovenije. Kranj: Fakulteta za podiplomske državne in evropske študije.

The Basic Constitutional Charter on the Sovereignty and Independence of the Republic of Slovenia from June 25, 1991, Official Gazette of RS, no. 1/91-I in 19/91 - corr.

The Constitutional Court of the Republic of Slovenia. U-I-266/95 from November 20, 1995. Retrieved September 26, 2016, from http://odlocitve.us-rs.si.

The Constitutional Court of the Republic of Slovenia. U-I-109/10 from September 26, 2011. Retrieved September 26, 2016, from http://odlocitve.us-rs.si.

The Constitution of the Republic of Slovenia from December 28, 1991. Official Gazette of RS, no. 33/91-I, with amendments and supplements.

Treaty on European Union. (2007). Consolidated version 2012. OJ C 326. 13-390. Retrieved September 26, 2016, from http://eur-lex.europa.eu.

Universal Declaration of Human Rights. 1948. Retrieved September 26, 2016, from http://www.un.org.

Vienna Declaration and Programme of Action. (1993). Retrieved September 26, 2016, from http://www.ohchr.org.

Waldron, J. (2009). Dignity, Rank and Rights. The Tanner Lectures on Human Values. Delivered at California, Berkeley. April 23, 2009. Retrieved December 12, 2016, from http://tannerlectures.utah.edu/_documents/a-to-z/w/Waldron_09.pdf.

Waldron, J. (2013). Is Dignity the Foundation of Human Rights? Public Law and Legal Theory Paper Series. Working paper 12-73. New York University, School of Law. Retrieved November 13, 2016, from: http://lsr.nellco.org/nyu_plltwp/374. 